\title{
Editorial - Número 2 - Grad+ Desdobramentos, Ampliações, Continuidades
}

\author{
Prof. Thiago Mio Salla e Prof. Eder Cassola Molina
}

A Revista de Graduação USP, ou apenas Grad+, celebra a publicação de seu segundo número. Sem se afastar das diretrizes conceituais inicialmente traçadas, muito pelo contrário, seu desafio, agora, mostrou-se ainda maior: ampliar, matizar e diversificar o já abrangente leque de conteúdos, análises, discussões, experiências e práticas de ensino-aprendizagem divulgados no número de estreia. Mediante tal esforço, mais do que simplesmente dar continuidade a este recém-instituído fórum de reflexões e debates, espera-se ofertar mais elementos que corroborem a consolidação de Grad+ quer internamente, quer para além das fronteiras uspianas, no país e no exterior.

Em conformidade com tal perspectiva, procurou-se não apenas apresentar pesquisas, ações concretas, inovações didáticas e propostas pedagógicas ou de gestão acadêmica correlatas às que figuraram no primeiro número, mas também expandir os horizontes de $G r a d+$, de modo a que a revista passasse a abarcar outros temas e assuntos, para além da pluralidade já estampada em suas páginas. Entre tais elementos podem-se elencar: o ensino a distância; a parceria universidade-empresa; a proposta transversal de oficinas de epistemologia voltadas a estudantes de todas as áreas do saber; a produção de material didático com ênfase na especificidade do aluno de graduação brasileiro; a mensuração do grau de satisfação de formandos em determinado curso como ferramenta de aperfeiçoamento; a atenção para a figura dos monitores enquanto importantes agentes de ensino.

Logo de saída, na seção "Artigos", Marcel Joly e Jorge A. W. Gut apresentam um fruto da parceria tecnológica entre Petrobras e Universidade de São Paulo no campo do ensino de graduação: a criação de uma disciplina no curso de Engenharia Química que trabalha com os alunos os fundamentos da Pesquisa Operacional (PO), abordagem interdisciplinar e científica voltada à tomada de decisões. Sara Albieri, por sua vez, traz a proposta concreta de se trabalharem, nos primeiros anos da graduação, conceitos relevantes de Epistemologia como meio de problematizar o conhecimento recebido por parte dos alunos de modo a evitar um simples "adestramento cumulativo" e, em contrapartida, fomentar a educação científica verdadeiramente crítica.

Em "Efeito do Ensino Médio no Ensino Universitário Brasileiro do Século XXI", Bianca Maria Alves dos Santos, por meio de pesquisa empírica, procura analisar a passagem do Ensino Médio para o Ensino Superior, discutindo como as deficiências encontradas no primeiro repercutem no desempenho dos graduandos no segundo. Ao mesmo tempo, busca também dimensionar o impacto, nos estudantes, da entrada na universidade, sobretudo no que se refere ao processo de transição significativa nos métodos de aprendizagem de um nível para o outro. Com foco não no início, mas no fim da trajetória do aluno na graduação, Luciana Manzan Ferreira investiga o grau de satisfação de formandos, com vistas ao aperfeiçoamento do ensino. Nesse movimento, detecta a necessidade de incremento de estratégias pedagógicas inovadoras, bem como de um maior envolvimento dos docentes com os alunos.

Ainda entre os artigos, Paola Baccin discorre sobre as reflexões e as escolhas didáticas que resultaram na produção de um conjunto amplo de materiais didáticos empregados na graduação em língua italiana da Universidade de São Paulo. Diferentemente dos itens comercializados por grandes editoras, o maior mérito das videoaulas, apostilas e exercícios propostos por Baccin encontra-se no fato de levarem em conta as particularidades do público brasileiro, além de considerarem que nossos alunos aprendem a língua 
estrangeira aqui, no seu país de origem. Assim, há a possibilidade de se enfrentar, de modo mais efetivo, o inevitável choque cultural decorrente de tal processo e trabalhar as dificuldades relativas ao ensino e à aprendizagem do idioma em questão para brasileiros, sobretudo nos níveis iniciais.

Quanto aos relatos, segunda modalidade de colaboração aberta por Grad+, chama a atenção de início o trabalho de Enos Picazzio e Sonia Castellar que trata do primeiro curso de graduação semipresencial aprovado pela USP, o Curso de Licenciatura em Ciências (CLC). Os referidos autores discutem a perspectiva integrada e interdisciplinar proposta pelo CLC, destacando, de modo mais geral, que a modalidade $\mathrm{EaD}$ pode também proporcionar ótimos resultados, bem como corroborar a produção de material didático capaz de servir de apoio às licenciaturas presenciais na área de ciências.

Um grupo da Faculdade de Medicina da USP lança os holofotes para uma figura importante no dia a dia do ensino realizado em laboratórios e salas de aula, mas que nem sempre recebe a devida atenção: os graduandos responsáveis pelo trabalho de monitoria. Para tanto, apresentam os resultados de pesquisa feita com os alunos-monitores da disciplina Técnica Cirúrgica e Cirurgia Experimental. A partir de tal levantamento, procuram dimensionar o quanto a monitoria facilita a assimilação de conteúdos e o aprimoramento prático dos alunos que a exercem, além de lhes permitir a melhoria de outros atributos, tais como a comunicação interpessoal.

No que diz respeito a práticas e metodologias de ensino inovadoras, da Faculdade de Ciências Farmacêuticas vem a proposta de um jogo virtual voltado à fixação dos principais conceitos de Biossegurança. Trata-se do jogo Chemical Risk, que permite a simulação de um acidente químico em ambiente laboratorial, conferindo ao aluno a possibilidade de aplicar e consolidar conceitos que aprendeu em sala de aula. Ao mesmo tempo, do Instituto de Química de São Carlos vem uma proposta baseada no estudo de caso (variante da chamada Aprendizagem Baseada em Problemas), cuja resolução se pauta no Modelo de Tomada de Decisão de Kortland. Por meio de tal esquema, os critérios para avaliar soluções alternativas são formulados em direta conexão com a identificação do problema em questão, de modo a não só melhor embasar a resolução deste, como também, em sentido mais amplo, fomentar no futuro profissional a capacidade de tomar decisões.

Se, no primeiro número de Grad+, conferiu-se espaço ao processo de reestruturação curricular realizado pela Faculdade de Medicina, neste número avulta o trabalho coletivo e vertical de reforma da grade promovido pelo curso (bacharelado e licenciatura) de Artes Cênicas da Escola de Comunicações e Artes. Em linhas gerais, trata-se de uma iniciativa fundamentada na integração entre processos criativos e pedagógicos, partindo-se do pressuposto de que estes irrigam aqueles, tendo em vista a promoção de ações de caráter educativo e social. Como resultado, almeja-se um perfil multifacetado de egresso, capaz de atuar como artista-pesquisador-pedagogo.

De modo correlato, mas pontual, Alessandra Bizerra, Hamilton Haddad e Suzana Ursi, do Instituto de Biociências, relatam o esforço do curso de Ciências Biológicas em aproximar as habilitações do bacharelado e da licenciatura, de sorte que esta não seja encarada como mera complementação daquele. Para tanto, em chave metonímica, discorrem sobre a estruturação e os princípios da disciplina Introdução ao Ensino de Biologia, que procura integrar a prática da pesquisa com a atividade docente. Nesse mesmo diapasão, com vistas também a promover a articulação entre a formação universitária e as necessidades da escola básica, Barbara Corominas Valério trata do Programa de Estágios Supervisionados criado pelo Instituto de Matemática e Estatística. Tal iniciativa prevê a elaboração de projetos ou sequências didáticas a serem aplicados em salas de aula dos ensinos fundamental ou médio, o que acaba por congregar professores da rede estadual de ensino, docentes da USP e licenciandos, conferindo a estes a oportunidade de articularem teoria e prática no âmbito do próprio exercício do magistério.

Em vista do vasto conjunto de elementos aqui apresentados, almeja-se que Grad+, oxalá, continue a 
sua missão luzeira de trazer à tona reflexões, debates e propostas relativos à graduação e, assim, prestigiar o trabalho docente no âmbito da universidade e fomentar estudos e práticas de ensino-aprendizagem calcados na contextualização, na interdisciplinaridade e no incentivo à formação, nas mais variadas áreas do saber, de sujeitos ativos e críticos. As exigências intelectuais, culturais, educacionais, institucionais que conformam este projeto são inúmeras, mas o trabalho está apenas começando. 